\title{
Precious Items Piling up Like Mountains: Buddhist Art Production via Fundraising Campaigns in Late Koryŏ Korea (918-1392)
}

\author{
Maya Stiller
}

check for updates

Citation: Stiller, Maya. 2021.

Precious Items Piling up Like

Mountains: Buddhist Art Production via Fundraising Campaigns in Late Koryŏ Korea (918-1392). Religions 12: 885. https://doi.org/10.3390/ rel12100885

Academic Editor: Song-Chong Lee

Received: 7 September 2021

Accepted: 7 October 2021

Published: 15 October 2021

Publisher's Note: MDPI stays neutral with regard to jurisdictional claims in published maps and institutional affiliations.

Copyright: (C) 2021 by the author. Licensee MDPI, Basel, Switzerland. This article is an open access article distributed under the terms and conditions of the Creative Commons Attribution (CC BY) license (https:/ / creativecommons.org/licenses/by/ $4.0 /)$.
Kress Foundation Department of Art History, University of Kansas, Lawrence, KS 66049, USA; mstiller@ku.edu

\begin{abstract}
Considering visual culture alongside written source material, this article uncovers the socioeconomic aspect of Korean Buddhist monastic life, which has been a marginalized field of research. Arguing against the idea of an "other-worldly" Buddhism, the article specifically discusses the ways in which Buddhist monasteries conducted fundraising activities in late Koryŏ period (918-1392 CE) Korea. Via fundraising strategies, which targeted wealthy aristocrats as well as the commoner population, Buddhist monks managed the production and maintenance of Buddhist material culture, such as the construction of shrines, the casting of precious sculptures, and the carving of thousands of woodblocks used for the printing of sacred Buddhist scriptures. While the scholarship on Koryŏ Buddhism has traditionally focused on meditation, doctrine, state sponsored rituals, and temples' relationships with the royal court, this study expands the field by showing that economic activities were salient features of Koryŏ Buddhism "on the ground." By initiating and overseeing fundraising activities, Buddhist manager-monks not only gained merit, but also maintained the presence and physical appearance of Buddhist temples, which constitute the framework of Buddhist ritual and practice.
\end{abstract}

Keywords: Buddhism; Koryŏ period (918-1392); economic history; fundraising; Medicine Buddha; Koryŏ Tripitaka; woodblock prints; dedication materials (pokchangmul)

\section{Introduction}

Contrary to the conventional understanding of "other-worldly" Buddhist monks, studies on the economic history of Buddhism in China, Japan, and ancient India have shown that the idea of Buddhist temples and monks being removed from the mundane realm of financial matters is largely fictional (Colcutt 1982; Covell 2012; Gernet 1995, p. 6; Goodwin 1987, p. 12; Kieschnick 1997, p. 33; Schopen 1994, p. 527; Schopen 1995, 2000; Walsh 2010, pp. 167-86). Monasteries had to manage land, purchase ritual supplies, and finance the maintenance of monastic buildings and objects of worship in order to function as full-fledged religious institutions. Previous research by art historian Elizabeth Kindall and historian Timothy Brook, for example, has been largely conducted under the premise that patronage was at the financial core of any Buddhist institution. Studies by Janet Goodwin, and others, have argued that Buddhist economic activities were less motivated by financial need but rather driven by proselytization efforts (Goodwin 1994). However, recent works have shown that Buddhist monastics exercised agency in the management of economic enterprises with the primary purpose of generating income for the temple (Brook 1993; Kindall 2011; Mitchell 2016). Incorporated into this emerging trend, this article looks at Buddhist temple economics from a broad multidisciplinary perspective that combines methodologies and perspectives from Buddhist Studies, art history, and economic history.

By emphasizing the practical and economic pursuits of Koryŏ period (918-1392) Buddhist monastic life, this study asserts that Koryŏ Buddhist monks were in charge of the financial matters of their home monasteries, in contrast to previous studies of late imperial Chinese Buddhism, according to which Buddhist monasteries rarely controlled 
the economic resources necessary to operate a large institution due to the intervention of lay donors (see, for example, Brook 1993). In Koryŏ period Korea, monks took full charge. Fundraiser-monks successfully developed strategies in order to finance the production and maintenance of Buddhist material culture and architecture. Large scale projects could take several years to realize; for example, the construction of new shrines, the regilding of precious Buddhist sculptures, or the carving of the thousands of woodblocks used for the printing of precious Buddhist scriptures. This article discusses the ways in which such economic and commercial ventures helped Buddhist monasteries maintain a vital production agenda of material culture construction.

I will focus on an aspect of the Koryŏ Buddhist economy that has thus far received little attention in the scholarship: the organization of fundraising campaigns and the steps they took, from initiating to completing the project for which the monastery needed funding. ${ }^{1}$ Approaching Koryŏ Buddhism from an economic history perspective constitutes a method for stepping outside a longstanding analytic framework that has largely focused on Koryŏ Buddhist Zen philosophy, institutional history, and Sino-Korean relations. Studies include Robert Buswell's work on Chinul 知訥 (1158-1210) and his approach to sudden and gradual Zen practice, and Sem Vermeersch's publications about the institutional and political aspects of Buddhism as a state religion. Most recently, Richard McBride translated and annotated the works of Chŏnt'ae monk cum prince Üich'ŏn 義天 (1055-1101), in which he highlights Ǔich'ŏn's close interactions with high ranking Buddhist monks in Song China. Juhn Ahn provided a sociocultural approach to Koryŏ Buddhism, by discussing the social aspects of Buddhist ritual and its competition with Confucianism (Ahn 2018; Buswell 1991; Buswell 1999; Buswell 2009; McBride 2017; Vermeersch 2008).

Due to the ways in which Koryŏ Buddhism has been previously studied, the monasteries have been idealized as loci of meditational practice and pompous rituals, while ignoring the interpersonal relationships between monks and the population at large. Perhaps considered too mundane and, therefore, not worthy of further exploration, very few scholars have discussed the extensive socioeconomic dimensions of Koryŏ Buddhism, and their work is hardly recognized in the wider scholarship of Korean Buddhism due to the field's preference for more philosophical themes. Until the late 2000s, Koryŏ Buddhism historiography mainly focused on temple land when discussing Koryŏ temple economy and monastic endowments ( $p o$ 寶). However, then, in 2009, building on earlier scholarship that discussed the Buddhist monasteries' engagement in animal husbandry, weaving, and roof tile making, Yi Pyŏnghŭi showed that the Koryŏ temple economy also included various other commercial activities, such as money lending, manufacture, brewing, and the trade of firewood and salt (Yi Pyŏnghŭi 2009; Yi Pyŏnghŭi 2020). ${ }^{2}$ My work complements the scholarship by following a more holistic approach, considering not only historical material but also archaeological and art historical sources, which provide us with a more detailed, richer understanding of the ways in which the Koryŏ Buddhist temple economy worked.

In the field of Koryŏ Buddhist art history, leading scholars Chung Woothak and Ide Seinosuke used genre specific stylistic analysis to enrich our understanding of Koryŏ Buddhist painting and its relationship to Chinese Buddhist painting. Additionally, works by Jeong Eunwoo, Shin Eunjae, and Ch'oe Song-eun have broadened our stylistic and iconographic knowledge of Koryŏ Buddhist sculpture and the donor base of the objects enshrined inside Buddhist sculptures (pokchang 腹藏) (Ch'oe Song-eun 2013; Chung 2013; Ide 2005; Jeong 2013; Jeong and Shin 2017). Complementing existing art historical scholarship, this article provides a more fine-grained analysis of the entire process of Buddhist art creation, from the monks' fundraising efforts to the final completion of a repair and/or (re)construction project, instead of focusing almost exclusively on the physical features and philosophical contents of the "arts".

\section{Buddhist Monasteries' Regular Income and Fundraising Campaigns}

Koryŏ Buddhist monasteries were landowners who controlled about one sixth of all the arable land in Koryŏ territory. The monasteries received land and annual stipends 
of rice and salt from the royal court and were further supported by powerful local families (Vermeersch 2008, pp. 62-70, 271ff). Particularly in the early Koryŏ period, Buddhist temples largely depended on wealthy secular patrons. Monasteries also fulfilled fundamental socioeconomic roles, such as lending grain and offering lodging (Vermeersch 2004, p. 25). In response to sociopolitical and historical changes, Koryŏ Buddhist monasteries diversified their sources of income from the mid-Koryŏ onward, when royal and elite support broke away during the upheavals resulting in military rule (1170-1270) and Mongol occupation (1270-1356). Monasteries expanded their commercial activities and became integrated more deeply into the local economy to subsist. Instead of relying exclusively on their large estates, farmed by tenants or slaves, the monasteries increasingly charged fees for memorial services and drew profits from the operation of pawnshops and mutual financing associations. Monasteries also accrued interest from money lending, and received occasional donations from devotees during fundraising campaigns and during dharma assemblies. Concomitantly, we see the proliferation of privately owned votive shrines (wŏndang 願堂), a trend which further limited the financial support from noble families for unaffiliated monasteries. ${ }^{3}$

Korean Buddhist practices depended on a physical framework of temple architecture, paintings, sculptures, and scriptures, which required extraordinary expenditures and interaction between peer institutions, fellow monks and lay devotees to construct and maintain. One of the most powerful financial tools that the late Koryŏ Buddhist community employed for the construction and repair of Buddhist artifacts were fundraising campaigns. Fundraising was a short term solution for irregular expenditures requiring a substantial amount of resources that could not be covered by the monastery's general budget, such as the reconstruction of an entire monastic compound or the main temple hall, the recasting or repair of Buddhist sculptures or paintings, the retiling of a roof, the reconstruction of a pagoda, the printing of Buddhist scriptures, or the immense costs of a Buddhist ceremony performed over several days to several months. Fundraising campaigns were typically organized by a "chief solicitor monk" (hwajusŭng 化主僧) who was either self-appointed or appointed by an abbot or lay donor. The chief solicitor was often assisted by mendicant monks whose duty it was to beg for rice, oil, etc., by chanting and lecturing on Buddhist scriptures, standing at places where people would typically gather-such as wells and market places-and explaining the need for funding for their temple's reconstruction plans. ${ }^{4}$ On carriages pulled by oxen or horses, or by boat, the fundraiser-monks would then transport the donations of grains, cloth, and other material to their monastery where they would be used for the project.

The scale of fundraising depended on the size of the project. For small scale projects, fundraising by one or two fundraiser-monks in nearby villages was sufficient. For example, the construction of a portrait hall three bays in width for the eminent monk Naong 懶翁 (1320-1376) at Songch'ŏnsa 松泉寺 (in Yanggwang Province, present day Ch'ungch'ŏng Province) was realized by Naong's disciple Kangnyŏn 覺連, who was able to gather the material by embarking on a fundraising tour in the neighboring villages. ${ }^{5}$ For large scale funding projects, multiple parties were involved, including the fundraiser-monk and his helpers as well as the abbot and prominent lay supporters. Fundraiser-monks frequently went to the cultural and economic capital of Koryŏ, Kaegyŏng 開京, to increase their chances of gathering donors and resources.

A fundraising campaign commonly consisted of a variety of smaller projects that were aimed at enlarging and updating the monastery and increasing its spiritual cachet; for example, by printing the entire Buddhist canon, and commissioning the production of new gilt-bronze sculptures and ritual tools. Numerous sources from throughout Koryŏ attest to this practice. In 1216, the Buddhist icons and buildings of Pohyŏnsa 普賢寺, in Myohyangsan 妙香山， were completely destroyed by fire during the invasion of the Khitan. Hence, the fundraisermonk Hakchu 學珠 travelled to the capital. When explaining Pohyŏnsa's reconstruction plans to the gathering crowd, "the people happily listened and everyone including the king, feudal lords, high-ranking officials, virtuous men and female devotees donated precious 
items that piled up like mountains." Through these donations, the Pohyŏnsa monks were able to commission clay sculptures of Vairocana Buddha (K. Pirojanabul 昆盧遮那佛) and two attending bodhisattvas, Mañjuśrī (K. Munsubosal 文殊菩薩) and Samantabhadra (K. Pohyŏnbosal 普賢菩薩), decorated with gold, silver, and precious jewels (today, modern versions of these sculptures are enshrined in the main hall of the monastery, Figure 1). In addition, Hakchu used the remaining funding to commission ritual instruments, such as a bronze bell, a metal chime, an incense burner, and ceramic jars. ${ }^{6}$

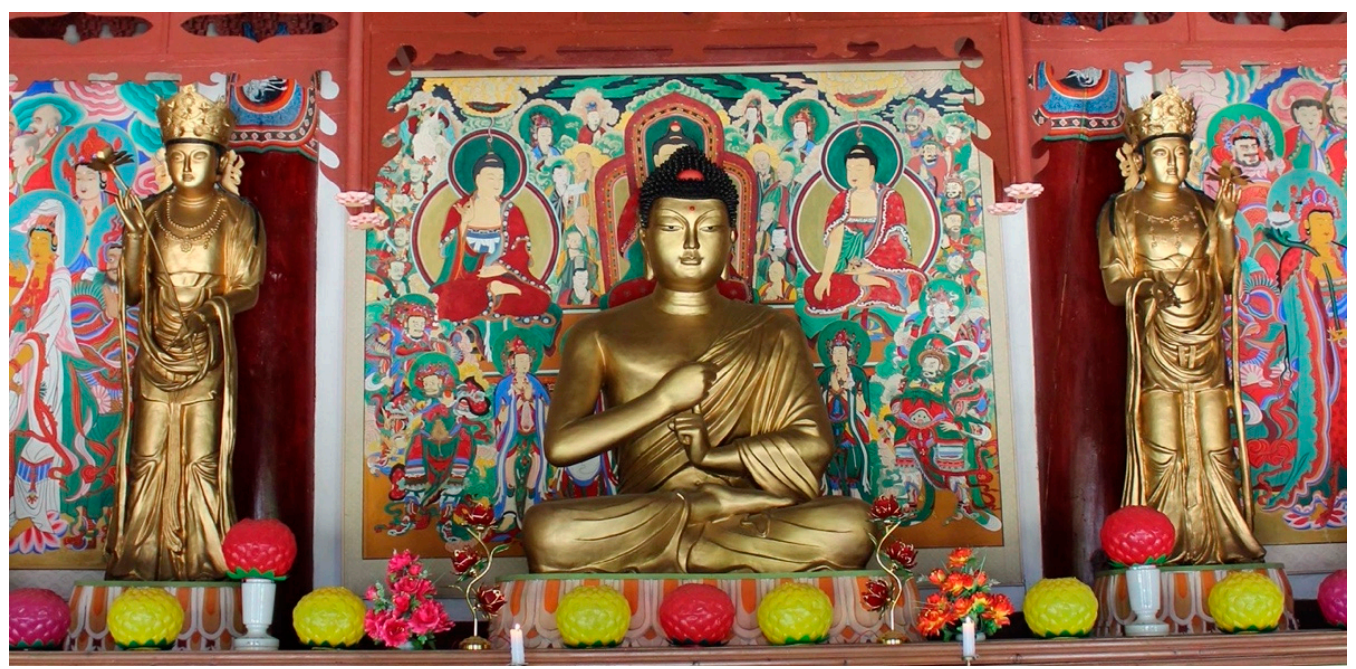

Figure 1. Vairocana Buddha with attending bodhisattvas, gold and colors on wood. Latter half of the twentieth century, Pohyŏnsa, Myohyangsan, North Korea. Source: Author.

Lay devotees most often donated grains, cloth (hemp, silk, ramie), and money. ${ }^{7}$ In some cases, they provided metal in the form of pots or mirrors. The royal court, government officials, monasteries, and sometimes also individual monks and laypeople, provided material supplies, such as timber and roof tiles, and labor force in the form of slaves and corvée laborers. An impressive array of donations is mentioned by Yi Kyubo 李 奎報 (1168-1241) in his recollection of a story about the monks Kŏbin 巨貧 and Kyogwang 晈光, who wanted to cast a gilt bronze Vairocana Buddha sculpture for the main hall of Wangnyunsa 王輪寺, a monastery in the northern part of Kaegyŏng. Their fundraising, however, did not go as planned. Extremely discontent with his inability to gather donors for his project, the old monk, Kŏbin, went to the Kŭmgang Mountains (Kŭmgangsan 金剛 山) and set himself on fire, whereupon Kyogwang, following Kŏbin's wishes, went on a fundraising tour with the cremated remains of his fellow monk. Impressed by the sad story, people of all social classes willingly provided donations. In addition to the usual offerings of rice and cloth, Kyogwang also received a number of unusual gifts. At $\mathrm{P}^{\prime}$ anbangni板方 里, for example, he encountered a destitute military commander (changgwan 將官) who donated his 13-year-old daughter, whom Kyogwang traded for $500 p^{\prime} i l$ 匹 of cloth to an old general who did not have any children and, therefore, wanted to adopt her. An impoverished widow in Sŏngdaedong 星臺洞 did not have anything to donate but a large precious bronze mirror, which was used later on in the casting of the statue. ${ }^{8}$

Most typically, while the monks would explain their projects verbally to attract a wide range of donors from all social classes, a letter lent credibility to the fundraiser's appeal to the literate. Sophisticated appeal letters written by renowned Buddhist monks such as Paegun 白雲 (1299-1374), or famous poets such as Yi Saek 李穡 (1328-1396), were used to attract potential donors among the literate, and increased the probability of gathering funding for the project in a relatively short amount of time. Referred to as yŏnhwamun 緣化 文, kwŏnsŏnmun 勸善文, or moyŏnmun 募緣文, the fundraising appeal letter explained the plans for using the funds. The head of the letter commonly discussed the general ideas of Buddhist doctrine, such as karmic retribution, followed by an introduction into the 
distinguished history of the temple that was in dire need for funding; the type of project that required funding; and the names of individuals who had initiated the project and had vowed to complete it. The fundraiser-monks' authority was reified by such appeals particularly when it bore a royal seal, since the population was obligated to cooperate with the royal court's wish/plan, expressed by the seal. ${ }^{9}$ A king's seal was also useful in order to request construction material and corvée laborers from government officials.

\section{Fundraising for Buddhist Icons with Mutual Support of the samgha}

Monks and nuns contributed significantly to (re)construction projects due to their wealthy aristocratic background. Ample evidence exists that testifies to their contributions. For example, for the reconstruction of Yunp'iram 潤筆庵 at Mijisan 彌智山 in present day Kyŏnggi Province, the nun Myodŏk 妙德 donated some of her assets. Myodŏk had formerly been Madam Im (Im ssi 任氏), with the honorific title Chŏng'an kunbuin 定安君夫人 (lit. "wife of Lord Chŏngan"). She likely became a nun after her husband died. ${ }^{10}$ Buddhist monks also supported the creation or restoration of Buddhist sculptures with their personal funds. In 1307, Royal Preceptor (wangsa 王師) Chin'gam 眞鑑 gave 16 kŭn 斤 of silver and 5 nyang 兩 of purple gold (the highest quality of gold) in order to repair and regild the Maitreya triad sculptures in the Golden Hall of Kŭmjangsa 金藏寺 at Yongdusan 龍頭山, in Chŏlla Province. Three years later, his disciple Koengji 宏之 was able to commission the painter-monk Chasŏng 自成 to regild the sculptures and repair their floral crowns, celestial garment, and jeweled pedestals. ${ }^{11}$

Members of the Buddhist clergy also aided in funding the expensive decoration of a Buddhist temple hall with tanch'öng 丹清 (lit. "red and blue"), which marked the last step of its construction. Tanch'ong, which refers to the decorative painting on the walls, pillars, and eaves of traditional Korean wooden buildings, could often not be completed due to its high costs. In 1324, the monk Sigyŏng'am 息影庵 was the abbot of Sŏnwŏnsa 禪源寺 in Yanggwang Province, which covers parts of present day Kyŏnggi and Ch'ungch'ŏng Province. He gave his disciple Chŏn'in 全忍 money from his personal funds to travel to Yuan China to purchase the mineral pigments required to decorate the temple's Vairocana Hall with tanch'ŏng. In 1325, after Chŏn'in succeeded in purchasing the material and with the additional use of $1000 p^{\prime} i l 匹$ of cloth, 100 sŏk 石 of rice, and 80 taels for corvée labor, the hall was decorated and also enlarged so it could seat 120 to 130 monks. Famous painter-monk Noyŏng 魯英 (act. early 14th century) decorated the ridges, while Haksŏn 鶴仙 painted forty guardian deities on its eastern and western wall, and an anonymous painter created the portraits of fifty five virtuous masters on the northern wall. ${ }^{12}$

A large reconstruction project that took place at Sŭngnyŏnsa 勝蓮寺, a monastery located in Namwŏn, Chŏlla Province, exemplifies the method of combining various resources, such as private funds from monks, with assets gained through local fundraising. When Choram 拙庵 (act. late Koryŏ) became abbot, he vowed to realize the plans of his teacher, National Preceptor Honghye (Honghye kuksa 弘慧國師, act. late Koryŏ), who had wanted to expand the temple. Similar to the Changgoksa Medicine Buddha sculpture project discussed below, in which the monk Paegun was the initiator and In'gyŏm was the fundraiser, in the case of Sŭngnyŏnsa, the initiator and "general manager" of the entire project was Choram, while Chŏnghan 宗閑 was in charge of fundraising. With Choram's management skills, Chŏnghan's fundraising efforts and funds from the monks' mutual aid assembly (契會 kyehoe), the Sŭngnyŏnsa monks were able to construct 111 bays of monastic buildings and could purchase ritual tools and items for daily use. Additionally, for Sŭngnyŏnsa's main hall, Choram personally funded the casting of an Amitābha Buddha (Muryangsubul 無量壽佛), and also donated slaves he had inherited from his wealthy parents. Furthermore, via fundraising in neighboring villages, the Sŭngnyŏnsa monks were able to obtain a printed version of the Buddhist canon that was enshrined to the right and left in the main hall. When Choram died, his disciple, cousin and successor Kagun 覺 雲 (act. late Koryŏ) built an outer wall around the monastery and thereby completed the extension project. After 36 years of construction work, in 1361, the completion ceremony 
was finally held..$^{13}$ The Sŭngnyŏnsa project is an excellent example that shows how much effort was required over the course of several dharma generations to complete a large-scale construction project, which included not only the building of monastic halls but also the production of Buddhist material treasures.

Monasteries belonging to the same Buddhist school also assisted each other by providing manpower and financial resources, attesting to the strong communal bonds within a particular school. For example, when Kaegukyulsa 開國律寺, a vinaya temple located in the southeast of Kaegyŏng, was largely destroyed by fire, the eminent monk Mokhŏn 木軒 (act. early 14th century) was able to reconstruct the monastery within only three years (1323-1325) by recruiting lay fundraisers who requested support from several other vinaya temples. The monks of Pŏbwangsa 法王寺, the Koryŏ period venue for the royally sponsored Eight Prohibitions Festival (P'algwanhoe 八關會), also located in Kaegyŏng, were able to construct and decorate a large Buddhist hall within a year. Fundraising for this project was organized by Sugong 修公 (act. late 13th century) and Ch'imgong 砧公, who was Hwaŏm master and leader of the Hwaŏm school (P'an Hwaŏm chongsa 判華嚴 宗事). Ch'imgong asked other Hwaŏm 華嚴 (Avatamsaka) temples for support, and also provided funds from his own personal wealth. Due to such generous funding, Pŏbwangsa was not only able to construct a new building but could also commission new paintings of a Vairocana triad and new portrait paintings of Hwaŏm patriarchs, which were hung in the center and on the left and right walls of the hall, respectively. ${ }^{14}$

Monk-fundraisers and their lay allies used material objects to attract funds from the largest possible number of people. Most common were the woodblock prints distributed among potential donors as objects of worship, good luck charms and an incentive for more donations. Although one of the earliest extant Korean examples of this practice dates from the sixteenth century, it is extremely likely that such practices existed already in the late Koryŏ period. In the third month of 1571, fundraiser cum woodcarver monk Hyesŏn 惠禪, from Powŏnsa 普願寺 at Sangwangsan in Ch'ungch'ŏng Province, together with a monk named Chihŏn 智軒 and a layman named Pak Onmun 朴彦文, provided the funds for the carving and first printing of a small woodblock featuring Buddha Sākyamuni preaching on Vulture Peak (Yŏngsanghoe 靈山會) (Figure 2). ${ }^{15}$ While more evidence needs to be found to substantiate this, the print was likely produced with the intent to distribute it widely in an effort to raise funds for Powornsa's Buddha hall reconstruction project, mentioned in the print's inscription. Thus, this print likely provides rare evidence for the distribution of Buddhist prints as a means to incentivize donations.

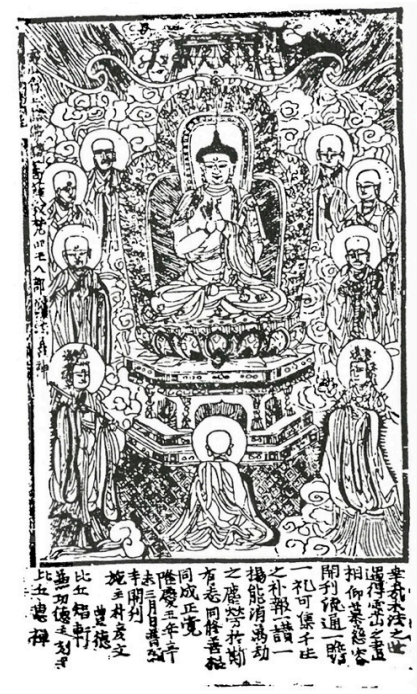

Figure 2. Vulture Peak Assembly, printed from woodblock with ink on paper. Originally carved in 1571, Chosŏn period (1392-1910). H $26.0 \mathrm{~cm}$ (10.2 inches), W $17.5 \mathrm{~cm}$ (6.8 inches). Currently in the collection of Kaesimsa, Sŏsan, Ch'ungch'ŏng Province. Source: (Pak 1987, p. 190). 


\section{Donors' Signatures and Prayer Texts for Funding the Changgoksa Medicine Buddha}

In the ritual context of the secret "eye-opening ceremony" (開眼供養 kaean kongyang) that transformed wooden or cast pieces of sculpture into powerful icons for worship, the Buddhist monks deposited prayer texts (parwŏnmun 發願文) inside Buddhist sculptures during Koryŏ and Chosŏn period Korea (1392-1910). Since these texts often contain a list of hundreds, sometimes even thousands, of donors' names, they are extremely important evidence for studying the wide range of social classes and individuals' motivations for contributing to Buddhist projects. ${ }^{16}$ Due to their portability and the potential to increase accountability among donors, it is highly plausible that fundraiser-monks used such prayer texts as appeal letters during fundraising tours. In exchange for a donation, potential donors added their names and prayers to an impressive list of officials and locally known individuals. Seeing those names also increased social pressure for potential donors to contribute.

Nine prayer texts discovered during the restoration work of a late Koryŏ period gilt-bronze Medicine Buddha at Changgok Monastery (Changgoksa 長谷寺) in the late 1950s are wonderful examples of prayer writing and signing practices. The longest prayer text in this assortment is a 417 inches long piece of red dyed silk, with a prayer text by Paegun 白雲 (1299-1374) including signatures by 1079 out of a total of 1117 names that had been written on all prayer texts (Figure 3). Paegun was a renowned late Koryŏ Buddhist monk who had a large number of aristocratic lay followers. Prior to practicing "phrase-observing meditation" (kanhwa sŏn 看話禪) after his return in 1351 from Yuan China (1271-1368), where he had studied with Buddhist meditational masters, he had become widely acknowledged as a monk with divine powers who performed rain prayers for the royal court (Koryŏsa 高麗史 54:27b (1346/6/3); Ch'oe Yŏnsik 2015, p. 43). Paegun's prayer text takes up approximately ten percent of the entire length of the silk piece, followed by the names of 1079 individuals' signatures and prayers written haphazardly onto the silk. The list includes names such as Bayan Temür (伯颜帖木兒, likely the Mongolian name of King Kongmin, 1330-1374, r. 1351-1374), and well-being wishes for the Yuan emperor, reflecting the fact that this document was written during the Mongol occupation period (1270-1356).

Paegun's prayer text was used during the fundraising campaign aimed at gathering funds for casting the Medicine Buddha at Changgoksa. Various passages in the text reveal that Paegun wrote this prayer text in a specific way so it could be used during the fundraising campaign. He encourages readers to worship the Medicine Buddha, since all their wishes will be fulfilled if they do and they will be reborn in Amitābha's pure land if they chant the Medicine Buddha's name and worship him. Paegun also writes that people who read and memorize the Medicine Buddha's teachings will be able to escape from the eight difficulties ( $p^{\prime}$ alnan 八難) of seeing the Buddha (Original text transcribed in Ch'oe Yonsik 2015, p. 31). He explains at great length the benefits of worshipping the Medicine Buddha, and that the making of a copper sculpture of the Medicine Buddha will result in the reception of merit and wisdom for his lay followers and dharma descendants. This prayer text proved to be extremely efficient in attracting donors, since more than one thousand individuals added their personal signatures to it. Fundraiser-monk In'gyŏm, whose name prominently appears twice on Paegun's prayer text, as well as on an individual prayer text discussed below, was most likely the person in charge of the fundraising tour, who would have displayed Paegun's prayer text as an incentive to potential donors.

The majority of the names on Paegun's prayer text are those of commoners. The calligraphic quality of their names varies greatly. Some names were written in haste, while others were written in clumsy characters, revealing that the writers were not very familiar with Sinitic characters. Some names were written in neatly arranged lines, while others are strewn across the surface, revealing that names were added in an uncoordinated manner. Since there were more individuals wanting to add their names than there was space, supporters also added their names between the lines of Paegun's prayer text and on the verso. More than sixty percent of the names appear in agnatic and associative clusters, 
and were written by one individual who wrote all the names of the respective group, while thirty percent are single names. Some individuals had an aristocratic background since they bear surnames, including 266 low ranking government officials and military officials; 22 local scholars, and 70 women with aristocratic status, among them 29 women with kunbuin 郡夫人 (lit. "wife of a lord") titles, attesting to the wide social range of donors to this project. ${ }^{17}$ Four separate pieces of exquisite fabric and silk brocade had been sewn onto the last portion of the piece. All four texts were written by aristocratic women of distinguished kunbuin status who wrote individual prayers to the Medicine Buddha, such as the wish to be reborn as a man and wishing a two-year-old child a long life (Jeong and Shin 2017, p. 191). These individuals likely donated to the project significantly more than others, and were therefore provided with the privilege to submit their own personal prayer texts. Alternatively, the social etiquette of the time might have made it difficult for elite women to see Buddhist male monks directly; hence, these textile pieces likely functioned as a bodily medium that substituted for the elite women's direct participation in signing the text.
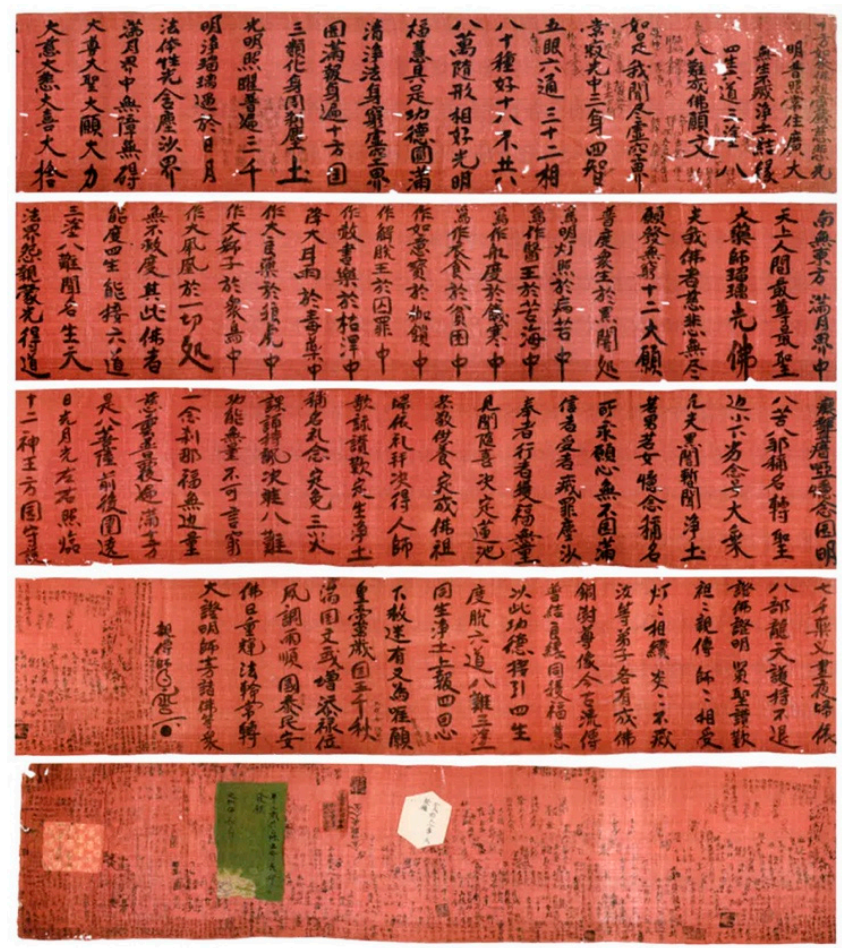

Figure 3. Prayer text by the monk Paegun and inscriptions of 1079 individual names, ink on red-dyed silk. Dated 1346, Koryŏ period (918-1392). L 1058 cm (417 inches), W 47.8 cm (18.8 inches). Originally stored inside the Medicine Buddha statue of Changgoksa, Ch'ŏngyang, Ch'ungch'ŏng Province. Source: (Jeong and Shin 2017, p. 178).

In addition to signing an existing prayer text during fundraising tours, individual devotees also wrote their own texts that were later added to the dedication materials (pokchangmul 腹藏物), in exchange for a donation. Aristocratic kunbuin, as well as Buddhist monks and common laypeople, provided their signature and prayers on eight separate small scraps of paper and different kinds of fabric. These eight texts had been written by single donors and groups of donors, consisting of 38 individuals in total. These individuals had made the largest contributions to the project, and were, therefore, given the privilege to write their names and personal wishes on separate pieces of fabric. One of these individual texts had been written on a piece of thick Korean mulberry paper (hanji 韓紙) in the shape of a sealed letter that is $30.6 \mathrm{~cm}$ long and $8 \mathrm{~cm}$ wide (12 inches by 3.1 inches) (Figure 4). The first name that appears on one side of this paper is of the monk In'gyŏm 忍謙 (act. mid 13th century) along with his title, "fundraiser-monk" (nokhwa toin 緣化道人), followed by the 
names and titles of two other monks. ${ }^{18}$ On the verso of this piece of paper an aristocratic woman, Nangnang kunbuin Madam Ch'oe, had written her name. Her title, "grand patron" (taegongdŏkchu 大功德主), shows that she must have been the primary contributor to the Medicine Buddha sculpture project. Other pieces written on silk or ramie cloth bear the male and female names of commoners who do not bear any specific titles. Instead, they express the wish for the health and safety of themselves and their children, and the wish to be reborn in paradisical realms. ${ }^{19}$ Although these individuals did not have as much spending power as members of the upper classes, they may have contributed significantly as a group, and were therefore allowed to submit an individual text with their names and short prayers.

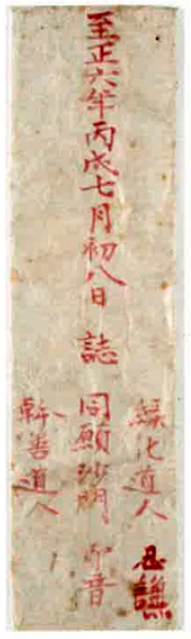

(a)

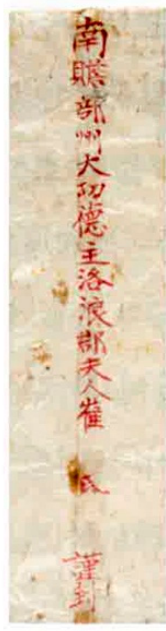

(b)

Figure 4. List of individuals including the monk In'gyŏm and Madam Ch'oe who contributed to the Medicine Buddha sculpture project, red ink on paper, (a) front and (b) verso. Dated 1346, Koryŏ period (918-1392). L $30.9 \mathrm{~cm}$ (12.1 inches). Originally stored inside the Medicine Buddha statue of Changgoksa, Ch'ŏngyang, Ch'ungch'ŏng Province. Source: (Jeong and Shin 2017, p. 182).

\section{Fundraising for the Sillŭksa Buddhist Canon}

The Sillŭksa 神勒寺 Buddhist Canon is a fascinating example that reveals intricate details about the material culture involved in a major Buddhist fundraising project. The project went through various stages over the course of several dozen years, illustrating the complicated lifecycle of fundraising within the Buddhist community. Provenance research on this canon shows that, within the context of cultural diplomacy in the early Chosŏn period, Buddhist monasteries in Japan eventually became the Sillŭksa Canon's owners and benefactors.

There are seemingly conflicting narratives about the individuals in charge of the project. According to Yi Sungin's 李崇仁 (1347-1392) record of the “Tripitaka pavilion at Sillŭksa in Yŏhŭng county" (Yŏhŭnggun Sillŭksa taejanggakki 擥興郡神勒寺大藏閣 記), the project was realized through a collaboration between Yi Saek and the monks of Sillŭksa, a powerful monastery, in 1382, more than thirty years after it had been conceived by Yi's father Yi Kok 李穀 (1298-1351). Yi Sungin asserts that his friend Yi Saek had been motivated to realize this project since he felt indebted to his parents and King Kongmin 恭慗 (1330-1374, r. 1351-1374). Yi Sungin thereby emphasized his friend's filiality and loyalty as a royal subject. According to his narrative, Yi Saek's father, Yi Kok, had initially wanted to print the Buddhist canon. In 1350, when his mother died, Yi Kok made a vow in front of the Buddha to do so and had appointed the monk Ch'onggong 聰公 to manage the fundraising and printing of the canon. Upon Yi Kok's death, Ch'onggong notified Yi Kok's son, Yi Saek, about his father's wish. However, Yi Saek prioritized mourning his father and focusing on his career at the royal court, leading to the further postponement of 
the printing project. In 1379, Yi was pondering a way to honor both his mother and King Kongmin, who had died in 1371 and in 1374, respectively. At that time, Ch'onggong came to the capital to pray for the dead king and again reminded Yi Saek about his deceased father's wish. Since Yi Saek had a special relationship with the disciples of Sŏn 禪 master Naong 懶翁 (1320-1376), whose burial stupa inscription he wrote, he asked two of them, Mugŭp 無及 and Subong 琇峯, to help him realize the printing of the entire Buddhist canon that would be housed at the temple where Naong had resided, Sillŭksa.

The postscript of the printed Sillŭksa Canon, however, tells a different story. It suggests that it was not Yi Saek but Yŏm Hŭngbang 廉興邦 (?-1388) and his wife, Madam Cho (P'yŏngyang kunbuin Cho ssi 平壤郡夫人 趙氏), who were the main (financial) contributors to the project. In the postscript's list of donors, Yŏm and his wife are listed first, followed by high ranking government officials and their wives, and some Buddhist abbots and monks. ${ }^{20}$ At the time of the Sillŭksa printing project, Yŏm had been recognized as a meritorious subject since he had recaptured the Koryŏ capital Kaegyŏng during the Red Turban attacks in 1362. However, in 1388, only a few years after completing the Sillŭksa Canon project, Yŏm received the death penalty due to his involvement in a land theft scandal (Koryŏsa 高 麗史 126:27a-29a).

Yi Saek is not listed as a contributor in the postscript's list of donors; perhaps he lacked the funds for a large financial contribution. However, as a talented writer, Yi supported the fundraising campaign through his texts; for example, by writing personal poems to acquaintances that the monks would visit on their fundraising tour. He sent a poem to high ranking government official Yi Chasu 李子修 (d.u.), in which he indirectly requested that Yi Chasu support the Sillŭksa Buddhist Canon project by saying that "where we meet is in [our efforts for] the Tripitaka." ${ }^{21}$ At the request of Yŏm Hŭngbang, Yi Saek also wrote the postscript to the printed canon. Such literary contributions greatly exemplify how renowned members of Koryŏ society, such as Yi Saek, contributed to a Buddhist fundraising campaign by offering their cultural capital.

While renowned monks and talented scholars provided their cultural and social capital to Buddhist fundraising projects, eloquent Buddhist monks also earned merit by traveling around the country to collect financial contributions. In the case of the Sillŭksa Canon project, fundraiser-monks Mugŭp and Subong organized a cross regional campaign in the second lunar month of 1380. They sent Sillŭksa monks to different regions in the peninsula: Kakch'am 覺旵, Kakcham 覺岑, Kakhong 覺洪, and Kagyŏn 覺連 went to towns in the central and southern part of Korea, such as Sunhŭng 順興, Andong 安東, Yŏnghae 寧海, and Ch'ungju 忠州, while Tohye 道惠 went to Ch'ŏngju 清州, and Chibo 志 寶 went to Aju 牙州. Two monks went even further north: Pŏm'ung 梵雄 to Pongju 鳳州 (now Pongsan) in Hwanghae Province, and Kagun 覺雲 to P'yŏngyang. ${ }^{22}$ Through such widescale fundraising efforts, the Sillŭksa monks were able to gather the funds necessary to commission the printing of the canon within less than a year (Figure 5). 


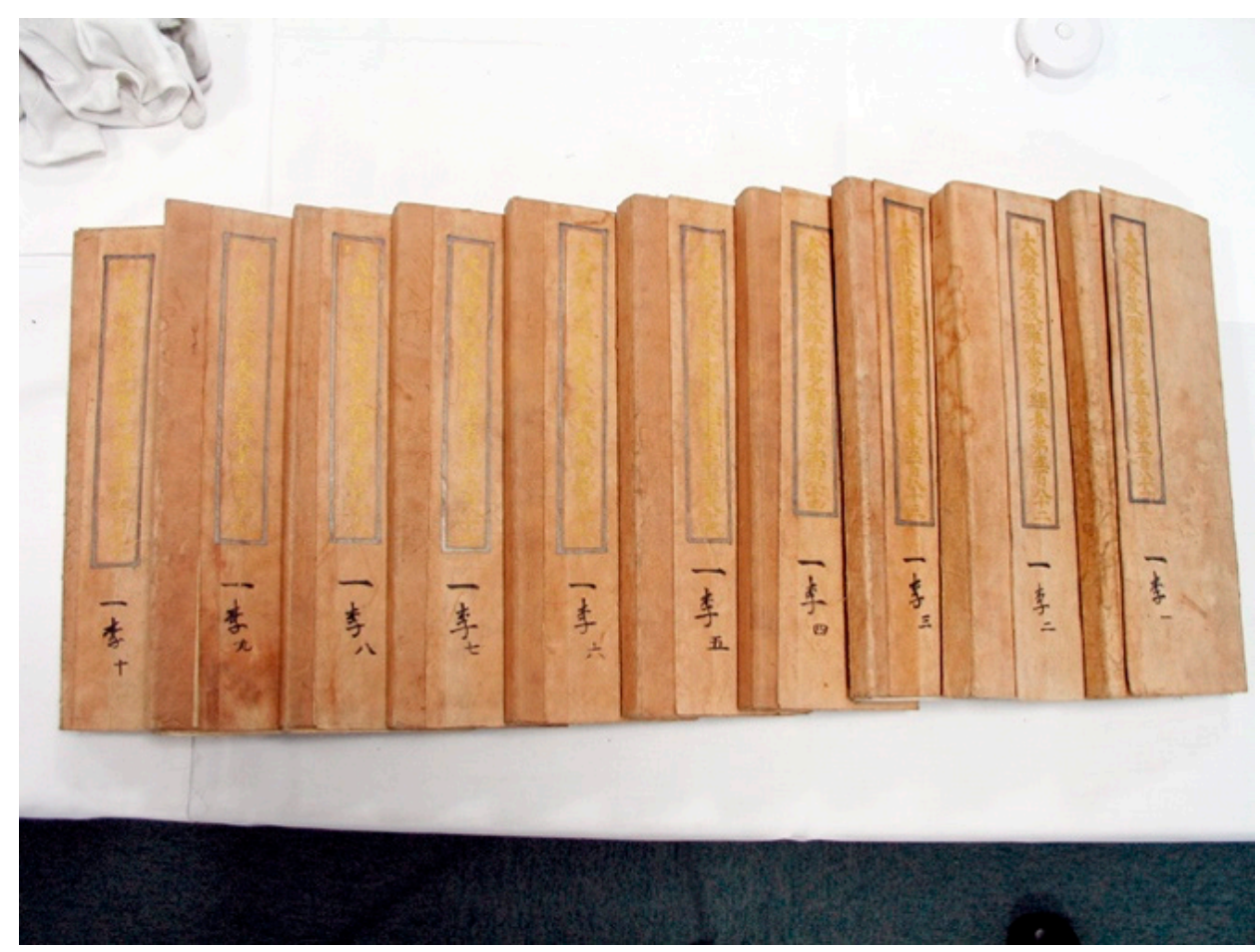

Figure 5. Sūtra on the Great Perfection of Wisdom (Taebanya paramilta kyŏng 大般若波羅蜜多經), volumes printed from woodblock in ink on paper, part of the Sillŭksa Canon. Dated 1382, Koryŏ period (918-1392). L 49-53 cm (19.3-20.8 inches), W 28 cm (11 inches). Collection of Otani University, Kyoto. Source: https://www.ibulgyo.com/news/articleView.html?idxno=94611 (accessed on 15 August 2021).

\section{The Realization of the Sillŭksa Canon}

Under the management of the monk Suam Munjangno 睡荑 文長老, the printing of the canon began in the fourth month of 1381 at Haeinsa 海印寺, where the woodblocks of the Koryŏ Canon were (and still are) housed. ${ }^{23}$ Sillŭksa had provided the print managermonk Suam with the material necessary for the printing, such as mulberry paper and ink made from black soot, and possibly some workers as well. By the ninth month of 1381, the printing and binding of all 5605 volumes of the canon had been completed. In the tenth month, the monk Kakchu 覺珠 used golden ink to write the title tags that would be attached to the yellowish jackets (黃複 hwangbok) that Kakpong 覺峰 had prepared for each volume (Figure 4). By the twelfth month, the artisan-monk Sŏnggong 性空 had built the 587 lacquered wooden boxes that would be used to store the volumes (Figure 6). ${ }^{24}$ Then, in the first month of 1382, the copy was moved to Yŏngt'ongsa 靈通寺 in Hwanghae Province, where monks well versed in doctrinal studies proofread the entire copy. Finally, in the fourth month of 1382, the completed set was moved by boat to Sillŭksa. A total of 263 donors, including local women, royal family members, high-ranking officials, aristocratic women, and eminent Buddhist monks, had previously contributed to the construction of the two-story Tripitaka Shrine (Taejanggak 大藏閣), where the scriptures were housed from the fifth month of 1382 onward. 

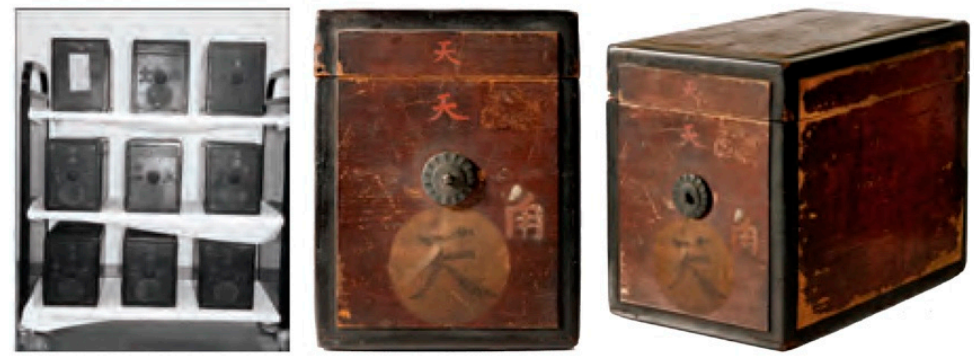

Figure 6. Wooden boxes with chrysanthemum shaped metal decoration; black and red lacquer on wood. Dated 1382, Koryŏ period (918-1392). W 23.6 (9.3 inches), L 32.1 (12.6 inches), H 25.3 cm (10 inches). Collection of Otani University, Kyoto. Source: (Jeong and Shin 2019, p. 48).

A large fundraising project, such as the Sillŭksa Canon printing project, consisted of various "mini-projects" to which individual believers contributed. Outstanding contributions were deeply appreciated by the monks and particularly mentioned in texts commemorating the event. For example, individual donors such as Hwasan 花山, Hong Uiryong 洪義龍, and Madam Kang (Kang puin 姜夫人) sponsored the making of the sculptures of Vairocana Buddha, Samantabhadra Bodhisattva and Mañjuśrī Bodhisattva that were enshrined in the building. Yi Sungin particularly notes that Hong had the statue of Samantabhadra cast to gain merit for his dead daughter. Furthermore, an old woman named Myoan, from Koksin-ri 國贐里, a village neighboring Sillŭksa, had supported the project by providing a substantial amount of grain to feed the monks while they were preparing the volume jackets and boxes for the printed volumes. ${ }^{25}$

Only 32 years later, in 1414, the Sillŭksa printed copy of the Koryŏ Canon became a useful item in the commodity diplomacy between Chosŏn Korea and Japanese feudal lords from Kyūshū (T'aejong sillok 太宗實錄 28:3b (1414/07/11)). From the late fourteenth to mid sixteenth centuries, the availability of Korean copies of Buddhist sūtras for the Japanese market was connected to domestic politics, as well as strategies for stopping piracy along the coast. The mobilization of sütras and other temple goods desired by Japanese elites mirrored the personal beliefs and policy programs of the Chosonn administration, which sought to remove Buddhist monks and institutions from political involvement. Thus, confiscated temple lands and dispersed Buddhist temple objects came to aid foreign policy programs. Additionally, in the late fourteenth and early fifteenth centuries, the southern coastline of Korea suffered from frequent attacks by Japanese pirates, who exhausted villages and storehouses, looted temple articles such as statues and sütras, and kidnapped men and women. Hence, the Chosŏn court conceived the idea of providing printed sūtras to Japanese envoys as part of an antipiracy program. Japanese elites and Ryukyuan kings approached Korean kings with requests for Buddhist sütras approximately one hundred times between 1388 and the mid sixteenth century. In turn, Korean kings granted about one half of these petitions (Hashimoto 2012, pp. 100-103). In exchange for the sütras, the Japanese elites offered the suppression of pirate attacks and the promotion of peaceful exchanges. By the 1410s and 1420s, i.e., around the time the Sillŭksa Canon was sent to Japan, the Chosŏn court had successfully promoted peaceful interaction and maritime piracy had substantially declined. ${ }^{26}$

It is in this political context that King T'aejong 太宗 (1367-1422, r. 1400-1418) granted the request of a Japanese envoy-monk named Keisu 圭壽, for a copy of the entire canon, and the Korean king provided Keisu with the Sillŭksa Canon, which consisted of 5605 volumes stored in 587 lacquered boxes. The Chosŏn royal annals mention that the canon was sent to the "king of Japan" (T'aejong sillok 太宗實錄 28:3b (1414/07/11)). The Sillŭksa Canon might have indeed been initially sent to the Ashikaga clan (Ashikaga shi 足利氏) that governed Japan until 1573, but it must have shifted into other hands swiftly, since it was first housed at a temple named Fukkōji 普光王寺 in Izumi Province 長門國 (in today's Fukuoka Prefecture), which was controlled by the Ōuchi clan (Ōuchi shi 大内氏) (Jeong and Shin 2019, p. 48). The Ōuchi were provincial governors based in western Honshu, 
who expanded into northern Kyushu several times. Along with the Sō clan (Sō shi 宗氏), who were the governors of Tsushima, and the Ashikaga clan, the Öuchi belonged to the three families who most frequently requested and received sūtras from Korea. Since the Ōuchi claimed descent from a Paekche prince named Imsŏng (Imsŏng t'aeja 琳聖太子) and participated in pirate suppression, Chosŏn kings had given them privileged access to trade with Korea. It is, therefore, highly likely that Keisu had been sent by the Ouchi and not by the "king of Japan."

In 1541, Ōuchi Yoshitaka 大内義隆 (1507-1551) passed the entire set to the shrine of Itsukushima 嚴島神社 in Hiroshima. The acquisition of the largest existing collection of Buddhist scriptures not only brought prestige to Itsukushima, but the Canon was a spiritual asset that was also extremely valuable for the Öuchi as a way to show their political power. The Sillŭksa Canon remained at the shrine throughout the Tokugawa period (1603-1867) but, due to the shinbutsu bunri 神仏分離 policy during the Meiji period (1868-1912) which was de facto an expulsion of Buddhist artifacts from Shinto-Buddhist shrines, the Canon was purchased by Higashi Honganji 東本願寺 in Kyoto, and since 1962 it has been housed at Otani University. A 2019 survey of the Sillŭksa Canon by Korean researchers showed that, in 1496, some of the volumes had been repaired using salmon pink jackets and title tags written in ink (Jeong and Shin 2019, pp. 42-43). However, in many volumes, the peach yellow jackets that Kakpong 覺峰 had initially created and the title tags written in gold by Kakchu 覺珠 are still intact. Furthermore, the lacquered boxes in which the volumes are currently stored seem to be the originals, which monk-artisan Sŏnggong 性空 and his team created (Figure 6).

It is an irony of fate that this precious canon was instrumentalized in the diplomacy efforts of the newly founded Chosŏn kingdom. From its conception in 1350, the Sillŭksa Canon illustrates the importance of fundraising to achieve a common goal-in this case, one with far reaching effects. With the result that its ultimate destination was the Japanese archipelago only a few years after the intense collaboration between Sillŭksa monks, lay patrons such as Yŏm Hŭngbang, Yi Saek, and several hundred supporters in the previous Koryŏ period donated to the project via financial and literary contributions. The canon exemplifies how successful fundraising campaigns in Korea inadvertently helped to suppress coastal attacks, as well as to expand the spiritual cachet of temples in Japan.

\section{Concluding Thoughts}

As previous studies by Robert Buswell, Richard McBride and others have shown, in the Koryŏ period there were undoubtedly monks who devoted their energies to meditation and deep doctrinal studies. However, the research presented in this article points to the fact that a substantial number of Buddhist monks were involved with securing funding and managing the realization of mundane temple projects. Since state support for Buddhist temples dwindled due to fiscal shortages during the late Koryŏ, Buddhist monks successfully employed fundraising campaigns in order to realize projects that went beyond providing for the livelihood of the temple community. Buddhist monks from wealthy family backgrounds used their personal funds, and they also reached out to aristocratic families and the general population to finance everything from casting ritual drums and incense burners, creating Buddhist sculptures and paintings, printing the Buddhist canon, and reconstructing pagodas and temple halls destroyed by fire or by invaders such as the Red Turbans, the Mongols, and Japanese pirates. Certainly, there were monks who rigorously searched for personal awakening, but the scholarship needs to acknowledge that there were also fundraising monks and administrator monks who were adept in exploiting the opportunities presented and thereby laid the financial foundations for the rich material culture of their monasteries, expressed in lofty temple buildings, delicate Buddhist sculptures, and precious woodblock printed books. Relying on talented fundraiser-monks and able project managers, Koryŏ period Buddhist monasteries were able to maintain and expand their monastic building space with the most impressive Buddhist art and material culture. 
Funding: The article processing charges related to the publication of this article were supported by the Kress Foundation Department of Art History at the University of Kansas (KU) and the University of Kansas (KU) One University Open Access Author Fund sponsored jointly by the KU Provost, KU Vice Chancellor for Research \& Graduate Studies, and KUMC Vice Chancellor for Research and managed jointly by the Libraries at the Medical Center and KU-Lawrence.

Institutional Review Board Statement: Not Applicable.

Informed Consent Statement: Not Applicable.

Data Availability Statement: Not Applicable.

Acknowledgments: The author would like to thank the participants in her graduate seminar "The Economics of Buddhist Art" for their feedback and suggestions on an earlier draft of this article.

Conflicts of Interest: The author declares no conflict of interest.

\section{Notes}

For a recent study on early modern Chinese Buddhist fundraising tactics see (Scott 2020).

(Han 1990; Vermeersch 2008, pp. 271-312; Yi Pyŏnghŭi 2009; Yi Sangsŏn 1991). Unless otherwise known, the names of Korean authors are transcribed using the McCune-Reischauer romanization system.

3 (Yi Pyŏnghŭi 2009). A monk in charge of the administrative affairs of a monastery, which also included financial affairs, was referred to as the chiksesŭng 直歲僧 (lit. a monk in charge of all temple affairs for a year) in the early Koryŏ period, when this monk was appointed by the abbot. In the late Koryŏ period, the abbot was in charge of all financial transactions, which led to the centralization and potential abuse of financial power. About the roles and functions of an abbot see (Han 1998, pp. 135-89).

4 Volume 5 in the Rules of Purity in the Chan Monastery (Chanyuan qinggui 禪苑清規) outlines the roles of chief solicitor and mendicant monks, see X 1245, 535a07-c13, http:/ / xn--tripiaka-ek0d.cbeta.org/X63n1245_005 (accessed on 15 August 2021). The Korean rearrangement and translation of the Rules in 2001 was based on an extant Koryŏ reprint from 1254, see (Chongsaek sŏnsa 2001). Not much research has been conducted since then on the use of the Chanyuan qinggui in the Koryŏ context, but it can be assumed that similar rules were known and implemented in Koryŏ monasteries.

5 Yi Saek 李穡 (1328-1396). “Ch’ŏngju Yongjasan Songch’ŏnsa Naong chindang ki” 清州龍子山松泉寺懶翁冥堂記. In Mogŭnsigo 牧隱詩葈, $6: 9 \mathrm{~b}-10 \mathrm{a}$.

6 Yi Kyubo 李奎報 (1169-1241). “Myohyangsan Pohyŏnsa tangju Piroch'ana yŏrae changyuk sosang ki” 妙香山普賢寺堂主毗盧遮 那如來丈六塑像記. In Tongguk Isanggukchip 東國李相國集, 24:15b-18a.

7 While different types of coins were introduced during the reigns of kings Sŏngjong 成宗 (961-997, r. 981-997), Mokchong 穆宗 (980-1009, r. 997-1009), and Sukchong 肅宗 (1054-1105, r. 1095-1105), the circulation of money was largely unsuccessful (Kim and Kim 2010). Generally speaking, the Koryŏ economy was a barter economy in which hemp clothing and grains were used as payment method.

8 Yi Kyubo 李奎報 (1169-1241). “Wangnyunsa changyuk kŭmsang yŏnghŏm susŭp ki” 王輪寺丈六金像靈驗收拾記. In Tongmunsŏn東文選, 67:9b-14a.

9 (Yi Pyŏnghŭi 2009, p. 191); For example, in 1366, when King Kongmin 恭慰 (1330-1374, r. 1351-1374) was mourning his wife and had handed royal power over to the monk Sin Ton 辛旽 (1323-1371), he signed a fundraising letter at Sin's request. In 1381, King U (1365-1389, r. 1374-1388), Kongmin's son, also supported Buddhist fundraising activities by adding his seal on fundraising letters (Koryŏsa 高麗史 132:5b; 134:29b).

10 Yi Saek 李穡 (1328-1396). “Ch’ŏngju Yongjasan Songch’ŏnsa Naong chindang ki” 清州龍子山松泉寺懶翁冥堂記. In Mogŭnsigo 牧隱詩蒷, 6:9b-10a.

111 nyang 兩 $=37.5 \mathrm{~g} ; 1$ kŭn 斤 = $630 \mathrm{~g}$; Yi San 李㦃 (act. late 13th century). “Kŭmjangsa kŭmdangju Mirŭk samjon kaegŭmgi” 金藏 寺金堂主彌勒三尊改金記. In Tongmunson 東文選, 68:5b-7b.

12 Sigyŏngam 息影庵 (d.u.). “Sŏnwŏnsa pirojŏn tanch’ŏnggi” 禪源寺毘盧殿丹青記. In Tongmunsŏn 東文選, 65:20b-21b.

13 Yi Saek 李穡 (1328-1396). “Sŭngnyŏnsa ki” 勝蓮寺記. In Mogŭn mungo 牧隱文莕, 1:9a-10b.

14 Yi Chehyŏn 李齊賢 (1288-1367). “Chungsu Kaegukyulsa ki“重修開國律寺記. In Ikchaenan'go 益齋亂橖, 6:17b-19b; Kwŏn Kŭn 權 近 (1352-1409). “Pŏbwangsa chosadang ki” 法王寺祖師堂記. In Yangch'onjip 陽村集, 10:11b-12a.

15 (Kim 2020, p. 19; Munhwa Chaech'ŏng 2015, pp. 482-83). Original and my translation of the inscription at the bottom of the print: 垂哉. 末法之世, 遇靈山之畫相. 仰慕慈容, 開刊流通, 一瞻一禮, 可集千生之补報.一讚一揚, 能消萬劫之塵勞. 於斯有志, 同 修善根, 同成正覺. 隆慶五年辛未三月日普願寺開刊. 施主朴彦文, 豊德, 比丘智軒, 兼功德主刻手, 比丘惠禪. “Handing it down! In the age of the decline of the dharma, encountering a painting of Vulture Peak [Assembly], we admire the compassionate countenance [of Śākyamuni Buddha] and initiate the printing for circulation. Every time one gazes and prostrates [in front of the Buddha], one can gather the compensation of one thousand births. Every time [one] praises [the Buddha] and hangs [the print], one can eliminate the dirt of ten thousand kalpas. Devoted in this [path], we wish to cultivate wholesome roots and achieve 
awakening together. Initial printing at Powŏnsa in the third lunar month of the fifth year of the Longqing reign [of the Ming]. Donors Pak Ornmun and the monk Chihŏn from P'ungdŏk; patron-cum-carver monk Hyesŏn."

16 The meaning of parwŏnmun 發願文 changed over time. In Later Silla 新羅 (668-935), it mostly referred to a vow text written by a monk that had more doctrinal undertones and expressed the monk's aspiration for awakening or rebirth in a pure land. In the Koryŏ (and Chosŏn) periods, however, the term simply refers to a list of donors' names and their prayers. It is yet unclear whether donors officially vowed to support the temple's project by signing their name, similar to contemporary Christian churches in the United States having pledges for parishioners who tithe.

17 Kunbuin 郡夫人 was an honorific title for women who were either married to or were the mothers of top ranked government officials (third rank and higher).

18 In'gyŏm also added his name to the list of donors on Paegun's prayer text (Ch'oe Yŏnsik 2015, p. 34).

19 The inscription that includes the name of a fundraiser-monk reads as follows: 至正六年丙戌七月初八日 誌. 緣化道人忍謙. 同願 沙文印音. 幹善道人. 南贍部洲大功德主洛浪郡夫人崔氏 謹封, which can be translated as “Recorded on the eighth day of the seventh month in the pyŏngsul year, the sixth year of Toghon Temür/Zhizheng [1346], fundraiser-practitioner In'gyŏm; monk with the same wish In'ŭm; virtuous manager-practitioner [dharma name missing]; great donor Nangnang kunbuin Madam Ch'oe from Jambudvīpa respectfully sealing [the letter]." For a transcription and Korean translation of the inscriptions on all eight pieces of fabric see (Jeong and Shin 2017, pp. 181-83).

20 A photograph, transcription and Korean translation of Yi Saek's postscript has been published in Jeong and Shin (2019, p. 47).

21 Yi Saek 李穡 (1328-1396). “Ki Posŏng Yi Chasu p'ansa taejang yŏnhwa pigu ch’ŏngya” 寄甫城李子修判事大藏緣化比丘請也. In Mogŭnsigo 牧隱詩莕, 25:23a.

22 Yi Sungin 李崇仁 (1347-1392). 1406. “Yŏhŭnggun Sillŭksa Taejanggak ki” 驪興郡神勒寺大藏閣記. In Toŭnjip 陶隱集, 4:5a-8b.

23 Yi Sungin 李崇仁 (1347-1392). “Suam Munjangno injanggyŏng u Haeinsa” 睡菴文長老印藏經于海印寺. In Toŭnjip 陶隱集, 3:24b-25a. Since the Buddhist canon produced in thirteenth century Koryŏ contains many more scriptures than the Pali Canon, I refer to it as the Koryŏ Canon rather than using the popular term Koryŏ Tripitaka.

24 Sŏnggong could have been the head of a group of artisans who built the 587 boxes together.

25 Yi Sungin 李崇仁 (1347-1392). 1406. “Yŏhŭnggun Sillŭksa Taejanggak ki.” 驪興郡神勒寺大藏閣記. In Toŭnjip 陶隱集, 4:5a-8b.

26 (Lippit 2008, p. 197; Robinson 2001). The author would also like to thank Peter Shapinsky for his kind advice and reading suggestions.

\section{References}

\section{Primary Sources}

Chanyuan qinggui 禪苑清規. Available online: http:/ /xn--tripiaka-ek0d.cbeta.org/X63n1245_001 (accessed on 15 August 2021).

Chŏng Inji 鄭麟趾 (1396-1478), ed. 1451. Koryŏsa 高麗史. Koryŏ sidae DB, compiled by Kuksa P'yŏnch'an Wiwŏnhoe. Kwach’ŏn: Kuksa P'yŏnch'an Wiwŏnhoe. Available online: http:/ / db.history.go.kr/KOREA/item/level.do?itemId=kr\&types=r (accessed on 15 August 2021).

Kwŏn Kŭn 權近 (1352-1409). 1674. “Pŏbwangsa chosadang ki” 法王寺祖師堂記. In Yangch'onjip 陽村集, 10:11b-12a. Han'guk munjip ch'onggan DB, compiled by Han'guk Kojŏn Pŏnyŏgwŏn. Seoul: Han'guk Kojŏn Pŏnyŏgwŏn, 2009. Available online: http:/ / db.itkc.or.kr/inLink?DCI=ITKC_BT_0036A_V002_0295_IMG (accessed on 15 August 2021).

Sigyŏngam 息影庵 (d.u.). 1478. “Sŏnwŏnsa pirojŏn tanch'ŏnggi” 禪源寺毘盧殿丹青記. In Tongmunsŏn 東文選, 65:20b-21b. Han'guk kojŏn chonghap DB, compiled by Han'guk Kojŏn Pŏnyŏgwŏn. Seoul: Han'guk Kojŏn Pŏnyŏgwŏn, 2009. Available online: http:/ / db.itkc.or.kr/inLink?DCI=ITKC_GO_1365A_0680_010_0100_2007_002_XML (accessed on 15 August 2021).

T'aejong sillok 太宗實錄. 1431. Publ. in Chosón wangjo sillok 朝鮮王朝實錄. Compiled by Kuksa P'yŏnch'an Wiwŏnhoe (National Institute of Korean History). Kwach'ŏn: Kyŏnggido: Kuksa p'yŏnch'an wiwŏnhoe, 2006. Available online: http://sillok.history.go.kr/ search/inspectionMonthList.do (accessed on 15 August 2021).

Yi Chehyŏn 李齊賢 (1288-1367). 1698. “Chungsu Kaegukyulsa ki“ 重修開國律寺記. In Ikchaenan'go 益齋亂葈, 6:17b-19b. Han'guk munjip ch'onggan DB, compiled by Han'guk Kojŏn Pŏnyŏgwŏn. Seoul: Han'guk Kojŏn Pŏnyŏgwŏn, 2009. Available online: http:/ / db.itkc.or.kr/inLink?DCI=ITKC_MO_0011A_0090_020_0020_2003_A002_XML (accessed on 15 August 2021).

Yi Kyubo 李奎報 (1169-1241). 1478. “Wangnyunsa changyuk kŭmsang yŏnghŏm susŭp ki”王輪寺丈六金像靈驗收拾記. In Tongmunsŏn東文選, 67:9b-14a. Han'guk kojŏn chonghap DB, compiled by Han'guk Kojŏn Pŏnyŏgwŏn. Seoul: Han'guk Kojŏn Pŏnyŏgwŏn, 2009. Available online: http://db.itkc.or.kr/inLink?DCI=ITKC_MO_0004A_0260_010_0110_2003_A001_XML (accessed on 15 August 2021).

Yi Kyubo 李奎報 (1169-1241). 1724-1776. “Myohyangsan Pohyŏnsa tangju Piroch'ana yŏrae changyuk sosang ki” 妙香山普賢寺堂主毗 盧遮那如來丈六塑像記. In Tongguk Isanggukchip 東國李相國集, 24:15b-18a. Han'guk kojŏn chonghap DB, compiled by Han'guk Kojŏn Pŏnyŏgwŏn. Seoul: Han'guk Kojŏn Pŏnyŏgwŏn, 2009. Available online: http:/ / db.itkc.or.kr/inLink?DCI=ITKC_MO_00 04A_0260_010_0110_2003_A001_XML (accessed on 15 August 2021). 
Yi Saek 李穡 (1328-1396). “Chip'yŏnghyŏn Mijisan Yunp'iram ki” 砥平縣彌智山潤筆菴記. In Mogŭn mungo 牧隱詩橖, 4:12b-13b. Printed in 1626. Han'guk munjip ch'onggan DB, compiled by Han'guk Kojŏn Pŏnyŏgwŏn. Seoul: Han'guk Kojŏn Pŏnyŏgwŏn, 2009. Available online: http:/ / db.itkc.or.kr/inLink?DCI=ITKC_MO_0020A_0460_010_0090_2003_A005_XML (accessed on 15 August 2021).

Yi Saek 李穡 (1328-1396). 1626. “Ch'ŏngju Yongjasan Songch’ŏnsa Naong chindang ki” 清州龍子山松泉寺懶翁冥堂記. In Mogŭnsigo 牧 隱詩葈, 6:9b-10a. Han'guk munjip ch'onggan DB, compiled by Han'guk Kojŏn Pŏnyŏgwŏn. Seoul: Han'guk Kojŏn Pŏnyŏgwŏn, 2009. Available online: http:/ / db.itkc.or.kr/inLink?DCI=ITKC_MO_0020A_0480_010_0090_2003_A005_XML (accessed on 15 August 2021).

Yi Saek 李穡 (1328-1396). 1626. “Ki Posŏng Yi Chasu p'ansa taejang yŏnhwa pigu ch'ŏngya” 寄甫城李子修判事大藏緣化比丘請 也. In Mogŭnsigo 牧隱詩橖, 25:23a. Han'guk munjip ch'onggan DB, compiled by Han'guk Kojŏn Pŏnyŏgwŏn. Seoul: Han'guk Kojŏn Pŏnyŏgwŏn, 2009. Available online: http:/ / db.itkc.or.kr/inLink?DCI=ITKC_MO_0020A_0320_010_0910_2003_A004_XML (accessed on 15 August 2021).

Yi Saek 李穡 (1328-1396). 1626. “Song Naong cheja in taejang Haeinsa” 送懶翁弟子印大藏海印寺. In Mogŭnsigo 牧隱詩葈, 28:406b. Han'guk munjip ch'onggan DB, compiled by Han'guk Kojŏn Pŏnyŏgwŏn. Seoul: Han'guk Kojŏn Pŏnyŏgwŏn, 2009. Available online: http:/ / db.itkc.or.kr/inLink?DCI=ITKC_MO_0020A_0350_010_1260_2003_A004_XML (accessed on 15 August 2021).

Yi Saek 李穡 (1328-1396). 1626. “Sŭngnyŏnsa ki”勝蓮寺記. In Mogŭn mungo 牧隱詩橖, 1:9a-10b. Printed in 1626. Han'guk munjip ch'onggan DB, compiled by Han'guk Kojŏn Pŏnyŏgwŏn. Seoul: Han'guk Kojŏn Pŏnyŏgwŏn, 2009. Available online: http:/ / db.itkc.or.kr/inLink?DCI=ITKC_BT_0020A_0430_010_0080_2008_010_XML (accessed on 15 August 2021).

Yi San 李㦃 (act. late 13th century). 1478. “Kŭmjangsa kŭmdangju Mirŭk samjon kaegŭmgi”金藏寺金堂主彌勒三尊改金記. In Tongmunson 東文選, 68:5b-7b. Han'guk kojŏn chonghap DB, compiled by Han'guk Kojŏn Pŏnyŏgwŏn. Seoul: Han'guk Kojŏn Pŏnyŏgwŏn, 2009. Available online: http:/ / db.itkc.or.kr/inLink?DCI=ITKC_GO_1365A_0710_010_0040_2007_002_XML (accessed on 15 August 2021).

Yi Sungin 李崇仁 (1347-1392). 1406. “Suam Munjangno injanggyŏng u Haeinsa” 睡菴文長老印藏經于海印寺. In Toŭnjip 陶隱集, 3:24b-25a. Printed in 1406. Han'guk munjip ch'onggan DB, compiled by Han'guk Kojŏn Pŏnyŏgwŏn. Seoul: Han'guk Kojŏn Pŏnyŏgwŏn, 2009. Available online: https:/ / db.itkc.or.kr/dir/item?itemId=MO\#dir/node?dataId=ITKC_MO_0034A_0050_0 10_1000\&viewSync2= (accessed on 15 August 2021).

Yi Sungin 李崇仁 (1347-1392). 1406. “Yŏhŭnggun Sillŭksa Taejanggak ki” 驪興郡神勒寺大藏閣記. In Toŭnjip 陶隱集, 4:5a-8b. Han'guk munjip ch'onggan DB, compiled by Han'guk Kojŏn Pŏnyŏgwŏn. Seoul: Han'guk Kojŏn Pŏnyŏgwŏn, 2009. Available online: https:/ / db.itkc.or.kr/dir/item?itemId=MO\#/dir/node?dataId=ITKC_MO_0034A_0060_010_0030 (accessed on 15 August 2021).

\section{Secondary Sources}

Ahn, Juhn. 2018. Buddhas and Ancestors: Religion and Wealth in Fourteenth-Century Korea. Seattle: University of Washington Press.

Brook, Timothy. 1993. Praying for Power: Buddhism and the Formation of Gentry Society in Late-Ming China. Cambridge: Harvard University Press.

Buswell, Robert. 1991. Tracing Back the Radiance: Chinul's Korean Way of Zen. Honolulu: University of Hawai'i Press.

Buswell, Robert. 1999. Buddhism under Confucian Domination: The Synthetic Vision of Sŏsan Hyujŏng. In Culture and the State in Late Chosŏn Korea. Edited by Jahyun Kim Haboush and Martina Deuchler. Cambridge: Harvard University Press, pp. 134-59.

Buswell, Robert. 2009. Admonitions to Neophytes (Kye ch'osim hagin mun). In The Collected Works of Korean Buddhism. Edited by Robert Buswell. Seoul: The Jogye Order of Korean Buddhism, vol. 2, pp. 195-205.

Ch'oe Song-eun. 2013. Koryŏ sidae pulgyo chogak yŏn'gu. Seoul: Ilchogak.

Ch'oe Yŏnsik. 2015. Changgoksa kŭmdong yaksa yŏrae chwasang ŭi sinang naeyong kwa chejak chuch'e: Parwŏnmun naeyong ŭi kŏmt'o rŭl chungsim ŭro. Misulsa yŏn'gu 29: 29-49.

Chongsaek sŏnsa. 2001. Koryŏp'an Sŏnwŏn ch'ŏnggyu yŏkchu. Translated by Ch'oe Pŏphye. Seoul: Kasan Pulgyo Munhwa Yŏn'guwŏn.

Chung, Woothak. 2013. Representation Techniques of Koryŏ Buddhist Painting, Production Context and Purpose. In New Perspectives on Early Korean Art: From Silla to Koryŏ. Edited by Youn-mi Kim. Cambridge: Harvard University Press, pp. 50-62.

Colcutt, Martin. 1982. Five Mountains: The Rinzai Zen Monastic Institution in Medieval Japan. Cambridge: Harvard University Press.

Covell, Stephen. 2012. Money and the Temple: Law, Taxes, and the Image of Buddhism. In Handbook of Contemporary Japanese Religions. Edited by Inken Prohl and John Nelson. Leiden; Boston: Brill, pp. 159-76.

Gernet, Jacques. 1995. Buddhism in Chinese Society: An Economic History from the Fifth to the Tenth Centuries. New York: Columbia University Press.

Goodwin, Janet R. 1987. Alms for Kasagi Temple. The Journal of Asian Studies 46: 827-41. [CrossRef]

Goodwin, Janet R. 1994. Alms and Vagabonds: Buddhist Temples and Popular Patronage in Medieval Japan. Honolulu: University of Hawai'I Press.

Han, Kimun. 1990. Koryŏ sidae sawon po ŭi sŏlch'i wa unyŏng. Yŏksa Kyoyuk Nonjip 13: 361-91.

Han, Kimun. 1998. Koryŏ sawon ŭi kujo wa kinŭng. Seoul: Minjoksa.

Hashimoto, Yū. 2012. Itsuwari no gaikō shisetsu: Muromachi jidai no Nitchō kankei. Tokyo: Yoshikawa Kōbunkan.

Ide, Seinosuke. 2005. Kōrai butsuga no sekai: Higashi Ajia bijutsu ni okeru ryōbun to sono shosō. Kokka 1313: 19-37.

Jeong, Eunwoo. 2013. Mid-Goryeo Buddhist Sculpture and the Influence of Song-Dynasty China. Journal of Korean Art E Archaeology 7: $40-59$. 
Jeong, Eunwoo, and Eunjae Shin. 2017. Koryŏ ŭi sŏngmul, pulbokchang. Paju: Kyŏngin Munhwasa.

Jeong, Eunwoo, and Eunjae Shin. 2019. Ilbon Ot'ani taehak sojang Koryŏ taejanggyŏng in'gyŏngbon yŏn'gu. Munhwajae 52: 38-55.

Kieschnick, John. 1997. The Eminent Monk: Buddhist Ideals in Medieval Chinese Hagiography. Honolulu: University of Hawaii.

Kim, Chahyŏn. 2020. Korean Single-Sheet Buddhist Woodblock Illustrated Prints Produced for Protection and Worship. Religions 11: 647. [CrossRef]

Kim, Pyŏngin, and Toyŏng Kim. 2010. Koryŏ chŏn'gi kŭmsok hwap'ye wa chŏmp'o. Han'guksa Hakpo 39: 43-76.

Kindall, Elizabeth. 2011. Envisioning a Monastery: A Seventeenth-Century Buddhist Fundraising Appeal Album. T'oung Pao 97: 104-59. [CrossRef]

Lippit, Yukio. 2008. Goryeo Buddhist Painting in an Interregional Context. Ars Orientalis 35: 192-232.

McBride, Richard. 2017. Doctrine and Practice in Medieval Korean Buddhism: The Collected Works of Ǔich'ŏn. Honolulu: University of Hawai'i Press.

Mitchell, Matthew. 2016. Beyond the Convent Walls: The Local and Japan-wide Activities of Daihongan's Nuns in the Early Modern Period (c. 1550-868). Ph.D. thesis, Duke University, Durham, NC, USA.

Munhwa Chaech'ŏng. 2015. Han'guk ŭi sach'al munhwajae: 2014 chŏnguk sach'al mokp'an ilje chosa, volume 2: Ch'ungch'ŏngpukto Ch'ungch'ŏngnamdo. Seoul: Pulgyo Munhwajae Yŏn'guso.

Pak, Sangguk. 1987. Chŏn'guk sach'al sojang mokp'anjip. Seoul: Munhawjae Kwalliguk.

Robinson, Kenneth. 2001. Treated as Treasures: The Circulation of Sutras in Maritime Northeast Asia from 1388 to the Mid-Sixteenth Century. East Asian History 21: 33-54.

Schopen, Gregory. 1994. Doing Business for the Lord: Lending on Interest and Written Loan Contract in the Mulasarvastivada-vinaya. Journal of the American Oriental Society 114: 527-54. [CrossRef]

Schopen, Gregory. 1995. Monastic Law Meets the Real World: A Monk's Continuing Right to Inherit Family Property in Classical India. History of Religions 35: 101-23. [CrossRef]

Schopen, Gregory. 2000. The Good Monk and His Money in Buddhist Monasticism of 'The Mahayana Period'. The Eastern Buddhist 32: 85-105.

Scott, Gregory. 2020. Building the Buddhist Revival: Reconstructing Monasteries in Modern China. Oxford: Oxford University Press.

Vermeersch, Sem. 2004. Buddhism at the Center: The Temples of Kaesŏng and Their Socio-Political Role. Acta Koreana 7: 7-34.

Vermeersch, Sem. 2008. The Power of the Buddhas: The Politics of Buddhism during the Koryo Dynasty (918-1392). Cambridge: Harvard University Asia Center.

Walsh, Michael. 2010. Sacred Economies: Buddhist Monasticism and Territoriality in Medieval China. New York: Columbia University Press.

Yi Pyŏnghŭi. 2009. Koryŏ sigi sawŏn kyŏngjesa yŏn'gu. Seoul: Kyŏngin munhwasa.

Yi Pyŏnghŭi. 2020. Koryŏ sigi sawŏn kyŏngjesa yŏn'gu II. Seoul: Kyŏngin munhwasa.

Yi Sangsŏn. 1991. Koryŏ sawŏn ŭi sanghaengwi ko. Sŏngsin Sahak 9: 5-27. 